\title{
DETERMINAÇÃO DE TANINO EM PEDÚNCULO DE CAJU: MÉTODO DA VANILINA VERSUS MÉTODO DO BUTANOL ÁCIDO
}

Tânia da Silveira Agostini-Costa*

Embrapa Recursos Genéticos e Biotecnologia, Parque Estação Biológica, W5 Final, 70770-900 Brasília - DF

Andréa Lima e Marcelo Victor Lima

Embrapa Agroindústria Tropical, R. Dra. Sara de Mesquita 2270 Planalto PICI, 60511-110 Fortaleza - CE

Recebido em 10/9/02; aceito em 27/2/03

TANNIN IN CASHEW APPLE: VANILLIN VERSUS BUTANOL ACID ASSAY. To improve tannin assay in cashew apple, several parameters were examined, including (1) extraction solvents, (2) effects of water and boiling time on butanol acid reaction and (3) correlation between vanillin and butanol acid assay of tannin in cashew apples. The 50-70\% acetone extracted the greatest amount of tannin from cashew apples. Concentrations of water in butanol reagents were adjusted and boiling time of butanol reaction was reduced at $15 \mathrm{~min}$. Tannin of unripe cashew apples was purified on Sephadex LH-20, aiming to obtain tannin standard for butanol assay. The vanillin assay presented high correlation with the butanol acid assay.

Keywords: tannin; cashew apple; vanillin assay.

\section{INTRODUÇÃO}

O Brasil é pioneiro e líder no aproveitamento de pedúnculo de caju (Anacardium occidentale L.). Entretanto, a adstringência decorrente da presença natural de tanino vem sendo tradicionalmente referida como um dos principais obstáculos contra o aumento das exportações dos pedúnculos de caju. Os taninos são compostos fenólicos classificados em condensados e hidrolisáveis. Os taninos condensados ou proantocianidinas são polímeros de flavonóides, cujos monômeros são unidos por uma ligação carbono-carbono. Os taninos hidrolisáveis são ésteres de ácido gálico e de ácido hexahidroxidifênico e glicose, além de outros polióis. Em pedúnculos de caju são encontrados os taninos condensados ${ }^{1}$.

A grande variedade estrutural dos taninos, a natureza polimérica e a falta de padrões comerciais específicos dificultam a determinação destes compostos em alimentos. O método de Folin \& Denis, que se baseia no princípio da oxiredução, vem sendo extensivamente empregado na determinação quantitativa de taninos em pedúnculos de caju ${ }^{2-4}$. Entretanto, verificou-se que o ácido ascórbico ou vitamina $\mathrm{C}$, agente redutor naturalmente presente em concentrações elevadas no pedúnculo de caju, apresenta forte interferência no método de Folin \& Denis e o método da vanilina foi apresentado, portanto, como o mais indicado para a determinação analítica de tanino em suco de cajus.

Embora o reagente da vanilina detecte tanto flavonóides monoméricos quanto poliméricos, ele é específico para uma classe limitada de compostos que apresentam uma ligação simples na posição 2,3 e grupos hidroxila em posições alternadas no anel A. Leucoantocianidinas (catequinas) e proantocianidinas (taninos) reagem com a vanilina na presença de $\mathrm{HCl}$ para produzir um produto de condensação vermelho ${ }^{6}$. A catequina comercial é empregada como padrão.

O método do butanol ácido é referido como o melhor para determinação de taninos condensados, em função da alta seletividade ${ }^{7}$.

*e-mail: tania@cenargen.embrapa.br
Nessa determinação, as subunidades do tanino condensado são oxidativamente clivadas para fornecer antocianidinas, que são vermelhas em meio ácido. O desenvolvimento da cor é dependente do solvente e é reduzido pela presença de água, sendo que as condições da reação precisam ser rigorosamente controladas ${ }^{8}$. Como o ácido tânico e a catequina comercial não apresentam resposta positiva para esta reação, o tanino condensado precisa ser purificado em laboratório para ser empregado como padrão.

Considerando que a determinação de taninos envolve uma grande diversidade química de compostos fenólicos, que os métodos oxiredutométricos não são apropriados para determinação de taninos em pedúnculos de caju e derivados e que os procedimentos estabelecidos para determinação de taninos pelo método da vanilina em suco de caju não incluem processo de extração dos mesmos ${ }^{5}$, o objetivo deste trabalho foi i) padronizar o processo de extração para determinar taninos em pedúnculos de caju; ii) otimizar as condições para determinar taninos pelo método do butanol ácido em pedúnculos de caju e iii) estabelecer a correlação entre o método do butanol e o método da vanilina, avaliando a validade do método da vanilina como método de escolha para a determinar taninos em pedúnculos de caju e derivados.

\section{PARTE EXPERIMENTAL}

\section{Material}

Material vegetal

Os pedúnculos de caju foram obtidos nas Estações Experimentais da Embrapa em Pacajus e Paraipaba, CE, safras 2000 e 2001. Os pedúnculos (40 unidades) colhidos aleatoriamente pela manhã, em estado de maturação apropriado para o consumo in natura, foram selecionados (20 unidades), quarteados, homogeneizados em liquidificador e analisados em triplicata. Considerando a suposta presença de antocianidinas livres na película do pedúnculo de caju, que poderia causar interferência na reação da vanilina ${ }^{9}$, e resultados prévios indicando que a presença de taninos em pedúnculos de caju estaria concentrada principalmente na película, algumas análises de pedúnculos com e sem película foram realizadas em paralelo. 


\section{Reagentes}

Fase móvel forestal: ácido acético-HCl-água 30:3:10.

Butanol reagente: $95 \mathrm{~mL}$ de butanol, $5 \mathrm{~mL}$ de $\mathrm{HCl}$ e $0,1 \mathrm{~mL}$ de sulfato férrico amoniacal $4 \%\left(2,1 \mathrm{~g}\right.$ de $\mathrm{FeNH}_{4}\left(\mathrm{SO}_{4}\right)_{2}$ x $12 \mathrm{H}_{2} \mathrm{O}+17$ $\mathrm{mL}$ de $\mathrm{HCl}$ conc. $+33 \mathrm{~mL}$ de metanol).

A catequina empregada foi da marca Sigma, o $\mathrm{HCl}$ da marca Merck e os demais reagentes foram Vetec. O butanol oriundo de outras marcas nacionais (Synth e Química) não foi usado, pois não apresentou reação positiva para determinação de tanino.

\section{Métodos}

\section{Purificação do tanino}

Para a viabilização do método do butanol, o tanino presente em pedúnculos verdes de cajueiro anão-precoce $\mathrm{CP}-076$ foi extraído com acetona 70\%, purificado em Sephadex LH-20 conforme Terrill et $a l .{ }^{10}$ e liofilizado.

\section{Caracterização das antocianidinas}

Cerca de 3,5 mg do tanino liofilizado foram tratados com $6 \mathrm{~mL}$ de butanol-HCl 95:5 em ebulição por $50 \mathrm{~min}$, visando a liberação oxidativa das antocianidinas e caracterização das mesmas. $\mathrm{O}$ butanol foi evaporado com nitrogênio. As antocianidinas presentes no resíduo púrpura foram dissolvidas em pequeno volume de metanol acidificado e separadas por cromatografia em papel, empregando forestal como fase móvel, conforme Harbone ${ }^{11}$.

\section{Extração analítica de tanino}

Um grama de pedúnculo de caju previamente homogeneizado foi pesado em tubos de centrifugação de $50 \mathrm{~mL}$ com tampa rosqueada. A extração dos taninos foi feita com $10 \mathrm{~mL}$ de acetona $70 \%$, por $2 \mathrm{~h}$ à temperatura ambiente. Este intervalo de extração foi antecedido, intermediado e finalizado por 3 processos de agitação mecânica em vortex, durante 3 min cada. Encerrada a terceira agitação do tubo de ensaio, que foi realizada após as $2 \mathrm{~h}$ de extração, o extrato foi centrifugado e cuidadosamente filtrado em uma fina camada de lã de vidro, pois o papel de filtro adsorve os taninos. O filtrado foi recolhido em um balão de evaporação e o resíduo, que permaneceu no tubo de ensaio, foi novamente adicionado de $10 \mathrm{~mL}$ de acetona $70 \%$, agitado por mais 3 min em vortex, centrifugado e filtrado no mesmo balão de evaporação que recebeu a primeira fração do extrato. A acetona presente no extrato foi totalmente evaporada a vácuo e o resíduo aquoso foi transferido para balão de $25 \mathrm{~mL}$ e diluído com metanol. As reações específicas foram desenvolvidas em tubos de ensaio com tampa, envoltos por alumínio, pois a presença de luz afeta a estabilidade das reações ${ }^{12}$.

\section{Reação da vanilina}

Esta reação foi realizada conforme Broadhurst e Jones ${ }^{12}$, empregando-se a catequina como padrão. Para as análises simultâneas de pedúnculos com e sem película foi empregado um branco de amostra, conforme recomendação de Walton et al ${ }^{9}$.

\section{Reação do butanol ácido}

Esta reação foi realizada segundo Porter et al. ${ }^{8}$, com adaptações que foram incluídas i) na redução do teor de água no "butanol reagente", conforme disposto no item reagentes; ii) no tempo de reação, que foi reduzido de 45 para 15 min e iii) no emprego do tanino de pedúnculo de caju purificado como padrão.

Esta reação foi desenvolvida com $6 \mathrm{~mL}$ do butanol reagente e $1 \mathrm{~mL}$ de extrato. Os tubos foram agitados em vortex, por $1 \mathrm{~min}$, e colocados em banho-maria em ebulição, por 15 min. Os tubos foram resfriados em água e a absorvância das amostras foi lida em $559 \mathrm{~nm}$.
O branco, preparado conforme a amostra, não foi aquecido, pois a reação, contendo amostra e reagente, não se desenvolve sem ebulição.

\section{RESULTADOS E DISCUSSÃO}

Dentre os vários solventes avaliados, visando a extração de taninos em pedúnculos de caju, a acetona $50-70 \%$ apresentou extração 30-50\% superior, após a quantificação pelo método da vanilina (Figura 1). Este solvente também foi empregado com sucesso na extração de taninos em forrageiras ${ }^{10}$. Em leguminosas e sorgo ${ }^{13}$, o metanol contendo $1 \%$ de $\mathrm{HCl}$ apresentou um potencial de extração de tanino praticamente dobrado, quando comparado com o metanol puro, solvente comumente empregado na extração de taninos em sorgo. Os demais solventes avaliados para leguminosas e sorgo, etanol $60 \%$ e água, extraíram menos de $40 \%$ dos compostos fenólicos solúveis em metanol/ $\mathrm{HCl}$. No caso do pedúnculo de caju, os resultados foram bem diferenciados, evidenciando a importância da avaliação do solvente extrator em função da grande diversidade da constituição química, do grau de polimerização apresentado e do tipo de interação que estes compostos podem apresentar em diferentes fontes vegetais.

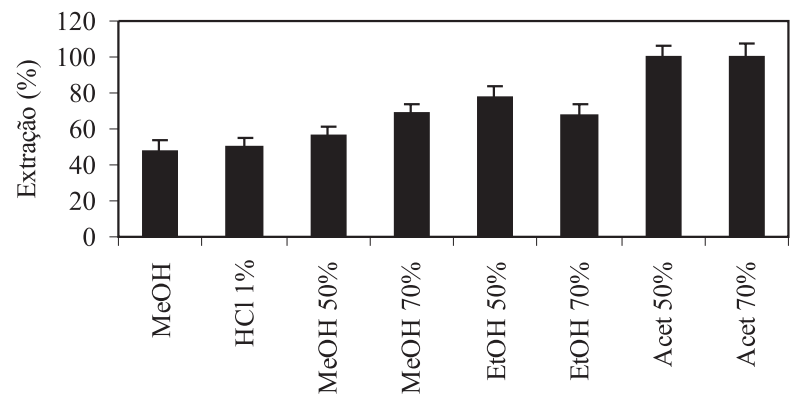

Figura 1. Influência do solvente na extração percentual de tanino determinado pelo método da vanilina; cada resultado é média de três repetições feitas para uma mesma amostra; $\mathrm{MeOH}$ : metanol; $\mathrm{HCl} \mathrm{1 \% :} \mathrm{em}$ metanol; EtOH: etanol; Acet: acetona

A reação original do butanol, desenvolvida para taninos extraídos de forrageiras, foi feita com extrato metanólico isento de água ${ }^{8}$. Para a determinação de tanino no pedúnculo de caju, cujo extrato final apresentou $28 \%$ de água, foi providenciada uma redução no teor de água do "butanol reagente" para compensar o conteúdo aquoso do extrato na reação final, uma vez que a alteração do equilíbrio aquoso reduz a sensibilidade da reação do butanol.

Para a determinação de taninos em Chaenomeles speciosa, a reação do butanol ácido foi desenvolvida por $40 \mathrm{~min}$ em ebulição ${ }^{8}$. Entretanto, para o tanino do caju nenhuma diferença significativa, em nível de 0,05 de probabilidade pelo teste de Tukey, foi observada entre os resultados após 15 min de reação (Figura 2). O tempo da reação foi reduzido, com manutenção da boa estabilidade e repeti-

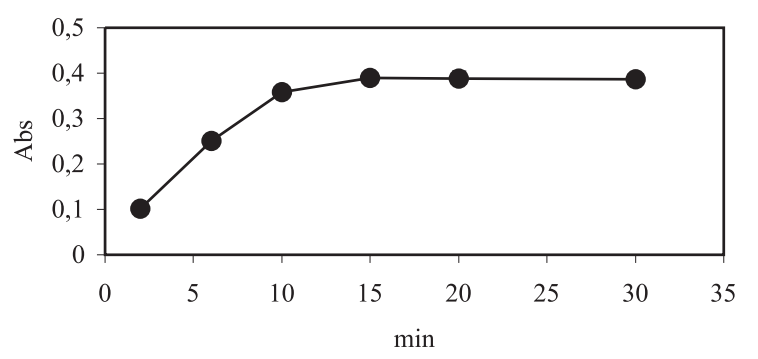

Figura 2. Influência do tempo de ebulição no desenvolvimento da cor da reação do butanol ácido, aplicada ao extrato tânico de pedúnculo de caju; cada resultado é média de três repetições 
bilidade do experimento. A resposta diferenciada, também neste caso, pode ser explicada pela grande variação estrutural que os taninos podem apresentar nas diferentes fontes vegetais.

A separação cromatográfica indicou a delfinidina (mancha pink; rf $=0,35$ ) como a principal antocianidina componente do tanino condensado purificado a partir do pedúnculo de caju. Além desta, outra mancha menos intensa, aparentemente pelargonidina (mancha vermelha, $\mathrm{rf}=0,76$ ), foi observada. As curvas de calibração para os métodos da vanilina e do butanol ácido, empregando-se tanino purificado como padrão, apresentaram boa linearidade entre $13 \mathrm{e}$ $260 \mu \mathrm{g} / \mathrm{mL}$. As repetições dos métodos apresentaram desvios padrão relativos inferiores a $5 \%$.

As análises de tanino pelos métodos da vanilina e do butanol ácido em vários lotes de pedúnculos de caju (Figura 3) apresentaram um alto coeficiente de correlação de Pearson $(0,98126)$, que foi significativo no nível 0,0001 de probabilidade. Embora o método do butanol seja mais específico para taninos condensados do que o método da vanilina, que também detecta monômeros, a alta correlação obtida entre os dois métodos indica que, em pedúnculos de caju, não existe quantidade significativa de flavonóides monoméricos com ligação simples na posição 2,3 e grupos hidroxila em posição alternada no anel A, condição exigida para reação com a vanilina.

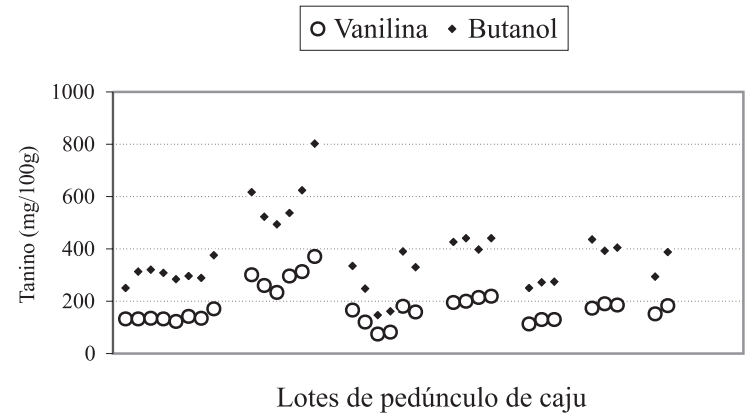

Figura 3. Correlação entre teores de tanino determinados pelos métodos da vanilina e do butanol em pedúnculo de caju; os pedúnculos foram procedentes de sete clones de cajueiro anão-precoce, analisados em diferentes lotes

A resposta do tanino para as duas reações, vanilina e butanol, é diferente, uma vez que as mesmas são baseadas em princípios químicos também diferenciados. Além disso, diferentes valores obtidos para o método da vanilina, empregando-se catequina e tanino purificado como padrões, são decorrentes das equivalências diferenciadas para os dois compostos ${ }^{10}$. Entretanto, para efeito de resultados comparativos, a catequina tem sido amplamente empregada na literatura, pois apresenta resposta satisfatória para essa reação e é facilmente obtida no mercado. O método do butanol ácido, cuja reação é baseada na clivagem oxidativa dos taninos condensados para fornecer antocianidinas, não apresenta reação positiva para a catequina.

Amostras compostas de pedúnculos de caju com película e despeliculados, procedentes de cajueiro microcarpum e de seis clones de cajueiro anão-precoce, foram simultaneamente analisadas. Neste caso, foi empregado um branco de amostra ${ }^{9}$, que indicou ausência de interferência significativa de antocianidinas no método da vanilina. Os resultados obtidos confirmaram resultados prévios, indicando que a presença de taninos, em pedúnculos de caju, está concentrada principalmente na película, que reteve percentual variável de tanino (Figura 4), influenciada pelo peso médio do pedúnculo. Os pedúnculos de cajueiro microcarpum, que apresentam peso médio reduzido e maior proporção de película, mostraram maior diferença entre os teores de taninos, quando analisados com e sem película. A presença de taninos em órgãos vegetais está associada à proteção das plantas, o que pode justificar a disposição dessas moléculas, em maior concentração, na superfície externa do pedúnculo (película).

sem película $\square$ com película

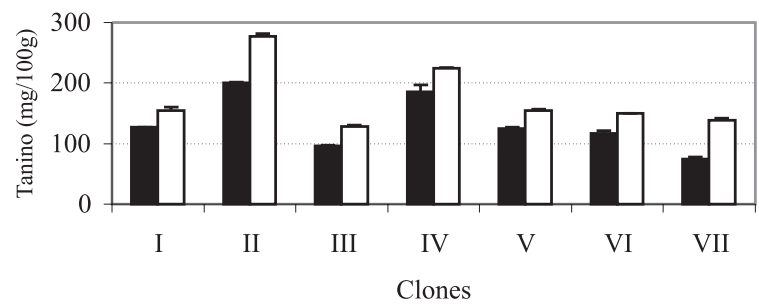

Figura 4. Teor de tanino em pedúnculos de sete clones de cajueiro anãoprecoce sem película e com película; cada resultado é média de três repetições

Os teores de tanino foram determinados pelos métodos da vanilina e do butanol em pedúnculos de cajueiro anão-precoce CP-076 maduros e verdes. Os pedúnculos maduros apresentaram teores de tanino $60-66 \%$ inferiores, quando comparados com pedúnculos verdes. Este resultado apresenta coerência com o processo de maturação dos pedúnculos, quando é observada uma redução acentuada da adstringência dos mesmos.

\section{CONCLUSÃO}

A acetona 50-70\% apresentou-se como o melhor solvente para extração de tanino em pedúnculos de caju. Os resultados fornecidos pelo método do butanol ácido apresentaram alta correlação com os obtidos pelo método da vanilina, indicando que o último pode ser empregado na determinação específica de taninos condensados em pedúnculos de caju. $\mathrm{O}$ teor de tanino determinado pelo método da vanilina, utilizando catequina como padrão, não deve ser interpretado como o conteúdo real de tanino em pedúnculo de caju, podendo ser empregado apenas para classificar comparativamente diferentes cultivares em relação aos demais.

\section{AGRADECIMENTOS}

Ao Banco do Nordeste do Brasil pelo suporte financeiro.

\section{REFERÊNCIAS}

1. Agostini-Costa, T. S.; Santos, J. R.; Garruti, D. S.; Feitosa, T.; Bol. CEPPA 2000, 18, 129.

2. Moura, C. F. H.; Dissertação de Mestrado, Universidade Federal do Ceará, Brasil, 1998 .

3. Pinto, S. A.; Dissertação de Mestrado, Universidade Federal do Ceará; Brasil, 1999.

4. Silva Junior, A.; Paiva, F. F. A.; Estudo físico e físico-químico de clones de cajueiros anão precoce, EPACE: Fortaleza, 1994.

5. Agostini-Costa, T. S.; Garruti, D. S.; Lima, L.; Freire, S.; Abreu, F. A.; Feitosa, T.; Bol. CEPPA 1999, 17, 167.

6. Deshpande, S. S.; Cheryan, M.; Salunkhe, D. K.; Crit. Rev. Food Sci. Nutr. 1986, 24, 401.

7. Hagerman, A. E.; Butler, L. G.; J. Chem. Ecol. 1989, 15, 1795.

8. Porter, L. J.; Hrstich, L. N.; Chan, B. G.; Phytochemistry 1986, 25, 223.

9. Walton, M.F.; Haskins, F.A.; Gorz, H.J.; Crop Sci. 1983, 23, 197.

10. Terrill, T.H.; Windham, W. R.; Evans, J. J.; Hoveland, C.S.; Crop Sci. 1990, $30,219$.

11. Harborne, J. B.; Comparative Biochemistry of the Flavonoids, Academic Press: New York, 1967.

12. Broadhurst, R. B.; Jones, W. T.; J. Sci. Food Agric. 1978, 29, 788.

13. Carmona, A.; Seidl, D. S.; Jaffé, W. G.; J. Sci. Food Agric. 1991, 56, 291. 